\title{
Acholeplasma laidlawii PG8 Culture Adapted to Unfavorable Growth Conditions Shows an Expressed Phytopathogenicity
}

\author{
Vladislav M. Chernov, Natalia E. Moukhametshina, Yurii V. Gogolev, \\ Tatiana N. Nesterova, Maxim V. Trushin*, and Olga A. Chernova \\ Kazan Institute of Biochemistry and Biophysics, Russian Academy of Sciences, \\ Kazan, Russia \\ E-mail: mtrushin@mail.ru
}

Received August 23, 2006; Revised December 19, 2006; Accepted December 20, 2006; Published January 10, 2007

Mycoplasmas are the smallest, self-replicating, prokaryotic organisms with avid biochemical potential and spreading in higher eukaryotes in nature. In this study, Acholeplasma laidlawii PG8 cells were cultivated on a deficient medium for 480 days resulting in a mycoplasma culture that was adapted in vitro to unfavorable growth conditions. Cells that survive this condition had decreased sizes (about $0.2 \mu \mathrm{m}$ ) and increased phytopathogenicity. This resulted in more frequent appearance of various morphological alterations when plants of vinca (Vinca minor L.) were infected by adapted mycoplasma cells. The increasing pathogenicity was accompanied by changes in genome expression in these adapted cells. Further studies are needed to explore the exact mechanisms that permit adaptation to unfavorable growth conditions and changes in phytopathogenic potential.

KEYWORDS: Acholeplasma laidlawii PG8, phytopathogenicity, ultramicroforms

\section{INTRODUCTION}

Mycoplasmas are the smallest, self-replicating, prokaryotic organisms. Despite restricted biochemical properties, these bacteria spread in various biotic communities and are able to persist in higher eukaryotes through their circulation in nature. It seems that the strong adaptability of these organisms resides in molecular genetic principles that permit them to adapt to unfavorable growth conditions (UGC). In our previous reports, we took some initial steps in exploring this adaptability[1,2], however, our knowledge of this mycoplasma potential is still in preliminary stages.

Acholeplasma laidlawii, a "ubiquitous" mycoplasma, is found in soil, compost, and wastewaters, as well as in tissues of humans, animals, and plants[3]. Previously, we showed that the adaptive reactions of A. laidlawii PG8 to UGC were connected with transformation of the vegetative forms of the mycoplasma cells into ultramicroforms (UMF) resistant to biotic and abiotic stress factors[1,2], a process that is called nanotransformation. Nanotransformation is not limited to mycoplasmas and has been shown in a number of bacteria. In some bacteria, adaptation to UGC was followed by distortions of pathogenicity. In our prior model of plant infection by mycoplasmas, we showed that A. laidlawii PG8 could cause 
phytomycoplasmosis[4,5]. In this study, we tried to show whether adaptation to UGC could affect the phytomycoplasmosis capability of A. laidlawii PG8 culture cells.

\section{MATERIALS AND METHODS}

Acholeplasma laidlawii PG8, a reference strain, was obtained from the N.F. Gamalei Research Institute of Epidemiology and Microbiology (Moscow, Russia). Mycoplasma cells were cultivated for 2 days at $37^{\circ} \mathrm{C}$ on Edward's medium ( 11 of this medium consisted of tryptic extract of bovine heart $-850 \mathrm{ml}$, serum of horse blood $-100 \mathrm{ml}$, fresh yeast extract $(5 \%)-40 \mathrm{ml}$, glucose [40\% solution] $-5 \mathrm{ml}$, benzylpenicillin $[1,000,000 \mathrm{IE} / \mathrm{ml}]-5 \mathrm{ml})$ to obtain a culture unadapted to UGC. To obtain a mycoplasma culture adapted to UGC, glucose and yeast extracts were eliminated from Edward's medium; microorganisms were kept in this condition for 480 days as was previously described[1]. To detect the titer of the colony-forming units (CFU), semifluid and solid-state variants of the Edward's medium with addition of $0.5 \%$ and $1.2 \%$ agarose were used. Two-dimensional protein electrophoresis was performed as was described by us[2]. PCR analysis of DNA was done using specific AL16LF and A23LR primers for amplifying nucleotide sequences of A. laidlawii PG8 rRNA operons as was previously reported[2].

The phytopathogenicity of the mycoplasma culture cells adapted and unadapted to UGC was investigated on substantive stalks of vinca (Vinca minor L.), a specific indicator of phytomycoplasmosis[6]. Both control and experimental groups consisted of 20 plants with similar size and age of the root. Plant seedlings were infected with mycoplasmas on the $15^{\text {th }}$ day after rooting. It was hypothesized that adapted culture of A. laidlawii PG8 has an increased phytopathogenic potential. To compare a level of its phytopathogenicity, we knowingly used a lesser amount of A. laidlawii PG8 cells adapted to UGCs. Our presupposition that a decreased number of cells may cause increased phytopathogenic alterations (in comparison with unadapted culture) was totally confirmed in our study (see results). We injected $10 \mu \mathrm{L}$ of $A$. laidlawii PG8 culture $\left(10^{5} \mathrm{CFU}\right.$ of adapted culture and $10^{7} \mathrm{CFU}$ of unadapted mycoplasma culture) by microsyringe into the root waist. In the control group, plants were injected with $10 \mu \mathrm{L}$ of sterile nutrient medium. Control and experimental plants were monitored for 6-8 weeks, a time necessary for manifestation of phytomycoplasmosis. The alterations in plant characteristics were recorded. These alterations were previously described[6] and included plant delay in bine growth, chlorosis, necrosis, leaf marcescence, and abnormalities in bine development.

A Hitachi-110 transmission electron microscope (Hitachi, Japan) was used for analysis of the in vitro cultivating mycoplasma cells. Ultrathin sections were obtained using LKB-III ultramicrotome (Sweden). The material under study was fixed with glutaraldehyde (2.5\%) prepared on a $0.1 \mathrm{M}$ phosphate buffer $(\mathrm{pH}$ 7.2) for $12 \mathrm{~h}$. Then, the material was dehydrated using an acetone series and postfixed in $0.1 \% \mathrm{OsO}_{4}$ with addition of $34 \mathrm{mg} / \mathrm{ml}$ of saccharose.

Numerical data are presented as mean \pm standard deviation. A probability level of $p<0.05$ was considered significant[7].

\section{RESULTS}

The adapted A. laidlawii PG8 cells showed significant reduction in size compared to unadapted cells (Fig. 1). On the solid medium, the UMF formed specific microcolonies $50-300 \mu \mathrm{m}$ in size. This is in contrast to typical mycoplasma cells that form "fried eggs" colonies. The UMF were able to revert into original vegetative forms of A. laidlawii PG8 cells when transferring to the full Edward's medium, showing an evident viability and resistance to stress factors. 

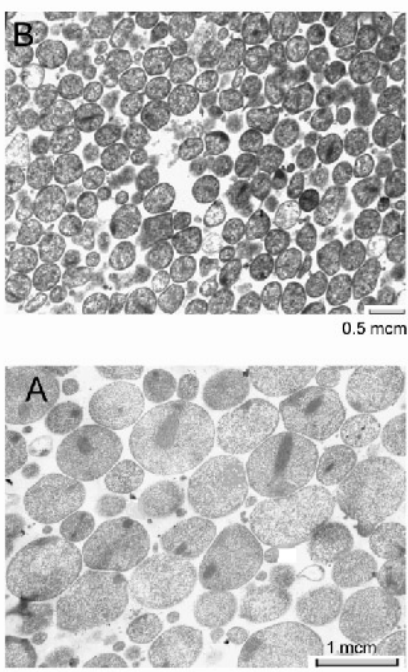

FIGURE 1. Electron micrography of A. laidlawii PG8 cells. Cultures were grown on Edward's medium for 2 days (A) and on the impoverished medium for 480 days (B).
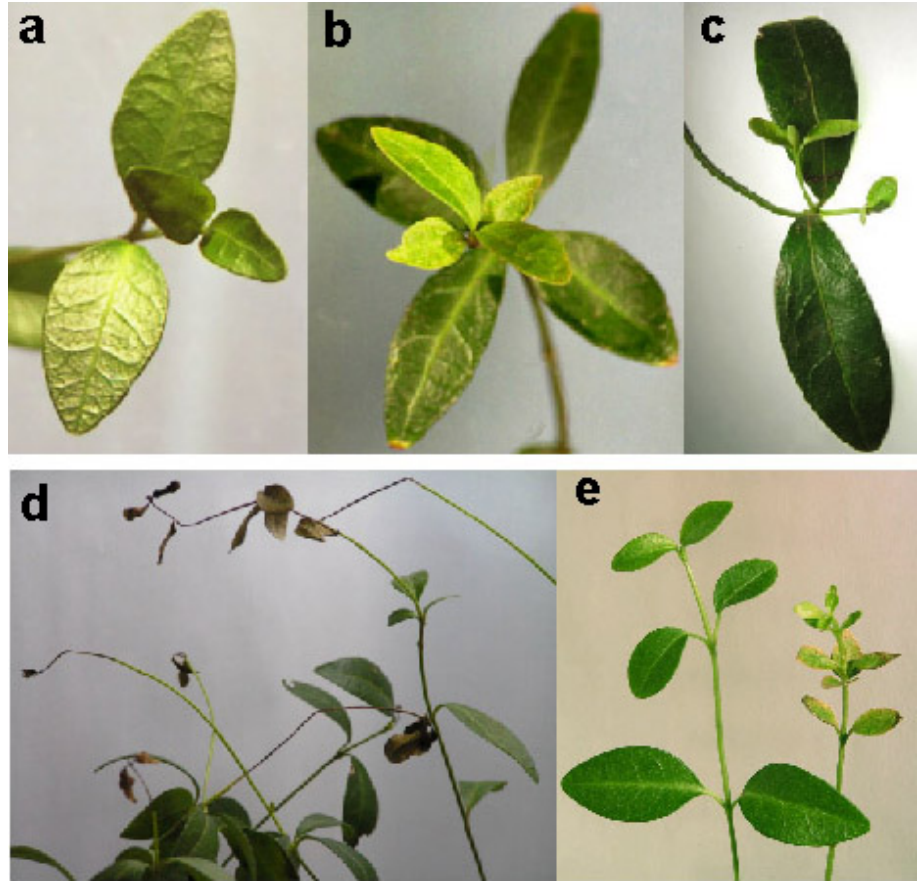

FIGURE 2. Morphosis in plants of $V$. minor L. infected by cells of A. laidlawii PG8 adapted culture. (a) Chlorosis and abnormalities of bine development (bulging of plant ribs); (b) necrosis (of the leaf edge); (c) abnormalities of bine development; (d) necrosis (of the apical leaves); (e) abnormalities of bine development (microplasia of the infected plant, right; normal plant, left).

Infecting plants of $V$. minor L. by A. laidlawii PG8 culture adapted in vitro to UGC resulted in the appearance of plant infection (Fig. 2). Plants infected by A. laidlawii PG8 culture unadapted to UGC showed significantly less signs of infection. For example, chlorosis was seen in $75 \%$ of plants infected with adapted mycoplasma in comparison with $40 \%$ in those with infection caused by unadapted 
mycoplasma. The other signs of infection were also more prevalent in adapted mycoplasma culture, such as necrosis by ( 50 vs. $25 \%$ ), leaf marcescence ( 50 vs. $25 \%$ ), and abnormalities of bine development (30 vs. $0 \%)$ (Table 1$)$.

TABLE 1

A Number of V. minor L. Plants with Various Morphological Deviations in Control and Experimental Groups*

\begin{tabular}{|c|c|c|c|c|c|}
\hline \multirow{2}{*}{$\begin{array}{l}\text { Variant of } \\
\text { Experiment }\end{array}$} & \multicolumn{4}{|c|}{ Type of Phytomycoplasmosis } & \multirow[t]{2}{*}{ Mean \pm SD } \\
\hline & Chlorosis & Necrosis & $\begin{array}{c}\text { Leaf } \\
\text { Marcescence }\end{array}$ & $\begin{array}{c}\text { Abnormalities } \\
\text { of Bine } \\
\text { Development }\end{array}$ & \\
\hline Control & $3(15)$ & $0(0)$ & $0(0)$ & $0(0)$ & $\begin{array}{c}0.75 \pm 1.5 \\
(3.75 \pm 7.5 \%)\end{array}$ \\
\hline Unadapted culture & $8(40)$ & $5(25)$ & $5(25)$ & $0(0)$ & $\begin{array}{c}4.50 \pm 3.32 \\
(22.5 \pm 16.58 \%)\end{array}$ \\
\hline Adapted culture & $15(75)$ & $10(50)$ & $10(50)$ & $6(30)$ & $\begin{array}{c}10.25 \pm 3.68 \\
(51.25 \pm 18.43 \%)\end{array}$ \\
\hline
\end{tabular}

* Absolute number of plants is indicated (percentage of the respective morphological deviations is shown in brackets).

The obtained results favor the hypothesis that adaptation in vitro of A. laidlawii PG8 culture to UGC was followed by a significant increase of its pathogenic potential.

\section{DISCUSSION}

Previously, we showed that adaptation of A. laidlawii PG8 culture to UGC was followed by nanotransformation, transformation of the vegetative form of cells of the mycoplasma into UMF resistant to biotic and abiotic stress factors[1,2]. There were noticeable differences in the morphological, biochemical, and genetic molecular properties between the vegetative form of cells of the mycoplasma and its UMF.

As a result of the analysis of two-dimensional electrophoresis data, significant differences in the cell polypeptide spectra of A. laidlawii PG8 culture adapted to UGC and the unadapted one were registered (Fig. 3). This might be evidence for an essential reorganization of the mycoplasma genome expression during nanotransformation, entering the vegetative form of cells of the mycoplasma into UMF due to UGC.

Other researchers have shown that there is a reverse attenuation of PCR signals for DNA of bacterial cells during cultivation in UGC[8]. Appearance of differential amplification of A. laidlawii PG8 rrnA and $r r n \mathrm{~B}$ nucleotide sequences due to dissociation of the cell culture population was reported in our recent study[9]. The data were considered to be useful to detect dissociation in cell population of the mycoplasma culture and to confirm transformation of the vegetative form of A. laidlawii PG8 cells into UMF in plant tissues.

In our previous experiments, we demonstrated that infecting by A. laidlawii PG8 culture unadapted to UGC was followed by the appearance of ultrastructural, morphophysiological, and biochemical deviations correlated with transformation of the vegetative form of the mycoplasma cells into UMF[1,2]. The data from our present study show that A. laidlawii PG8 culture adapted to UGC has higher expressive phytopathogenicity than the unadapted one. Even a 100-fold difference in a number of cells could not 


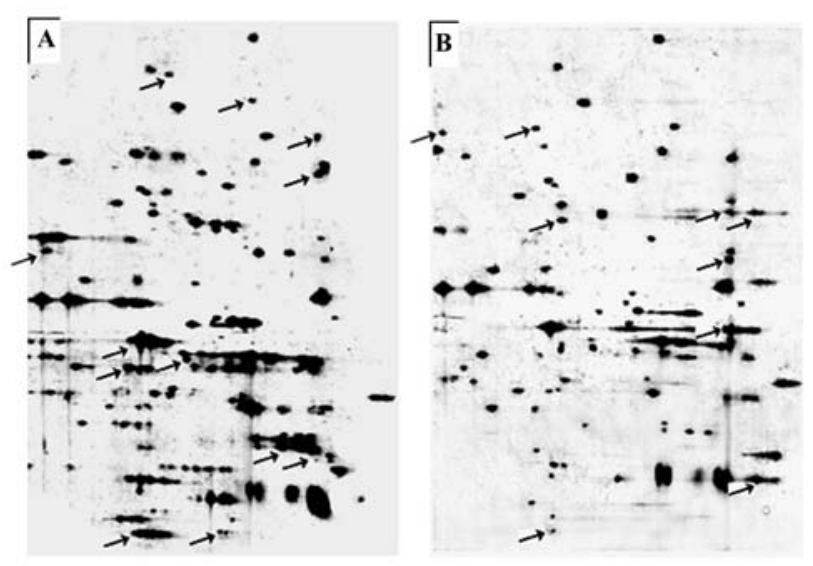

FIGURE 3. Electrophoregram of polypeptides of vegetative cells (A) and ultramicroforms (B) of A. laidlawii PG8. The arrows mark the polypeptides different in the mycoplasma cells.

influence the situation. In the plants infected by A. laidlawii PG8 unadapted to UGC culture, the symptoms of the mycoplasma infection were detected somehow later, and were less evident in comparison with the adapted mycoplasma culture (Fig. 4). A delayed manifestation of the mycoplasma infection by plants infected by unadapted mycoplasma could be related to the time that is needed for transformation of the vegetative form of cells into UMF. A comparison of the injected-adapted mycoplasma strain and the isolated one from the plants on biological differences remains to perform.

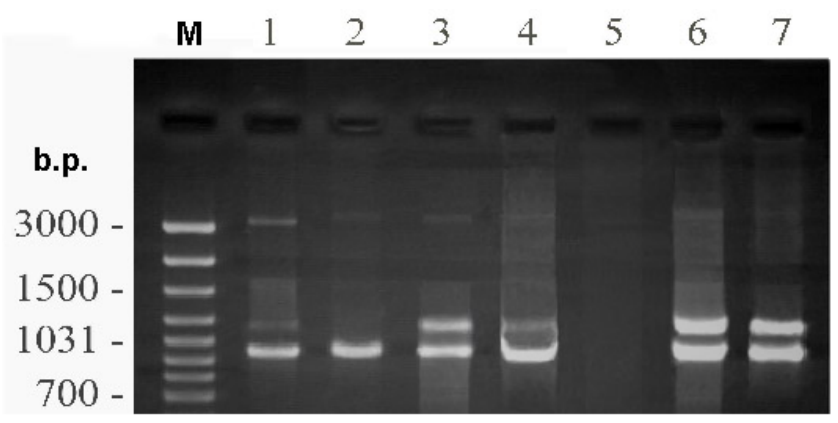

FIGURE 4. Detection of A. laidlawii PG8 by PCR with primers LA16LF and LA23LR in plants (V. minor L.). The lanes $1-4$ contain PCR products of DNA extracted from plants infected with cells of adapted $(1,2)$ and unadapted $(3,4)$ culture of the mycoplasma through 4 days $(1,3)$ and 21 days $(2,4)$ after injecting. The lanes $5-7$ correspond to negative $(5)$ and positive $(6,7)$ controls - PCR products of DNA $(230 \mathrm{ng})$ extracted from uninfected plants (5), mixed DNAs (230 ng/10 ng) of uninfected plants and cells of unadapted culture of the mycoplasma (6) and DNA (10 ng) extracted from cells of unadapted culture of the mycoplasma (7). The lane $\mathrm{M}$ corresponds to marker for length of DNA fragments (b.p.).

Changes in genome expression reorganization in bacteria adapting to UGC may explain the shift of bacterial metabolism and distortion or disappearance of virulence of some microorganisms $[9,10,11,12]$. However, this is the first report that shows that, at least in mycoplasma, adaptive processes were followed by an increase in pathogenicity. Further studies are needed to explore the exact mechanisms that permit adaptation to unfavorable growth conditions and changes in phytopathogenic potential. 


\section{ACKNOWLEDGMENTS}

The work was supported by the Russian Foundation for Basic Research (grant № 05-04-49435) and by the program of fundamental studies "Molecular and Cellular Biology" provided by the Russian Academy of Sciences, as well as by Government contract №02.442.11.7283.

\section{REFERENCES}

1. Chernov, V.M., Gogolev, Y.V., Mukhametshina, N.E., Abdrakhimov, F.A., and Chernova, O.A. (2004) Mycoplasma adaptation to biogenic and abiogenic stressful factors; Acholeplasma laidlawii nannotransformation and minibodies. Dokl. Biol. Sci. 396, 251-254.

2. Chernov, V.M., Gogolev, Y.V., Mukhametshina, N.E., Abdrakhimov, F.A., and Chernova, O.A. (2005) Adaptive reactions of mycoplasmas in vitro: "viable but unculturable forms" and nanocells of Acholeplasma laidlawii. Microbiologiya 74, 498-504.

3. Razin, Sh. and Herrmann R. (2002) Molecular Biology and Pathogenicity of Mycoplasmas. Plenum, New York.

4. Chernov, V.M., Gogolev, Y.V., Popova, N.V., and Chernova, O.A. (1996) Infections of Pisum sativum of Acholeplasma laidlawii PG8 lead to change of morphological and physiological features of plants. Dokl. Rus. Acad. Sci. 348, 428-430.

5. Chernov, V.M., Gogolev, Y.V., Popova, N.V., and Chernova, O.A. (1999) Genetic variance of mycoplasmas (Acholeplasma laidlawii) during their interaction with eukaryotes (Pisum sativum). Dokl. Rus. Acad. Sci. 369, 275277.

6. McCoy, R.E., deLeeuw, G.T.N., Marwitz, R., Chen, T.A., Cousin, C.J., Sinha, R.C., Petzold, H., Chiykowski, L.N., Coudwell, A., Chang, C.J., Dale, J.L., Golino, D., Kirkpatrick, B., Sugiura, M., Whitcomb, R.F., Yang, I.L., Zhu, BM., and Seemuller E. (1989) Plant diseases associated with mycoplasma-like organisms. In The Mycoplasmas. Whitcomb, R. and Tully, J.G., Eds. Academic Press, San Diego.

7. Sokal, R.R. and Rohlf, F.J. (1969) Biometry. The Principles and Practice of Statistics in Biological Research. Freeman, San Francisco.

8. Warner, Z.M. and Oliver, Z. (1998) Randomly amplified polymorphic DNA analysis of starved and viable but nonculturable Vibrio vulnigicus cells. Appl. Environ. Microbiol. 64, 3025-3028.

9. $\quad$ Chernov, V.M., Moukhametshina, N.E., Gogolev, Y.V., Nesterova, T.N., Trushin M.V., and Chernova, O.A. (2006) Differential amplification of Acholeplasma laidlawii PG8 rrnA and rrnB nucleotide sequences during dissociation of the cell culture population. J. Rap. Meth. Aut. Mic. 14, 369-376.

10. Baffone, W., Citterio, B., Vittoria, E., Casaroli, A., Campana, R., Falzano, L., and Donelli, G. (2003) Retention of virulence in viable but non culturable halophilic Vibrio spp. Int. J. Food Microbiol. 89, 31-39.

11. Grey, B. and Steck, T. (2001) The viable but nonculturable state of Ralstonia solanacearum may be involved in longterm survival and plant infection. Appl. Environ. Microbiol. 67, 3866-3872.

12. Khmel', I.A. (2005) Regulation of expression of bacterial genes in the absence of active cell growth. Genetika 41, $1183-1202$.

\section{This article should be cited as follows:}

Chernov, V.M., Moukhametshina, N.E., Gogolev, Y.V., Nesterova, T.N., Trushin, M.V., and Chernova, O.A. (2007)

Acholeplasma laidlawii PG8 culture adapted to unfavorable growth conditions shows an expressed phytopathogenicity. TheScientificWorldJOURNAL 7, 1-6. DOI 10.1100/tsw.2007.25. 

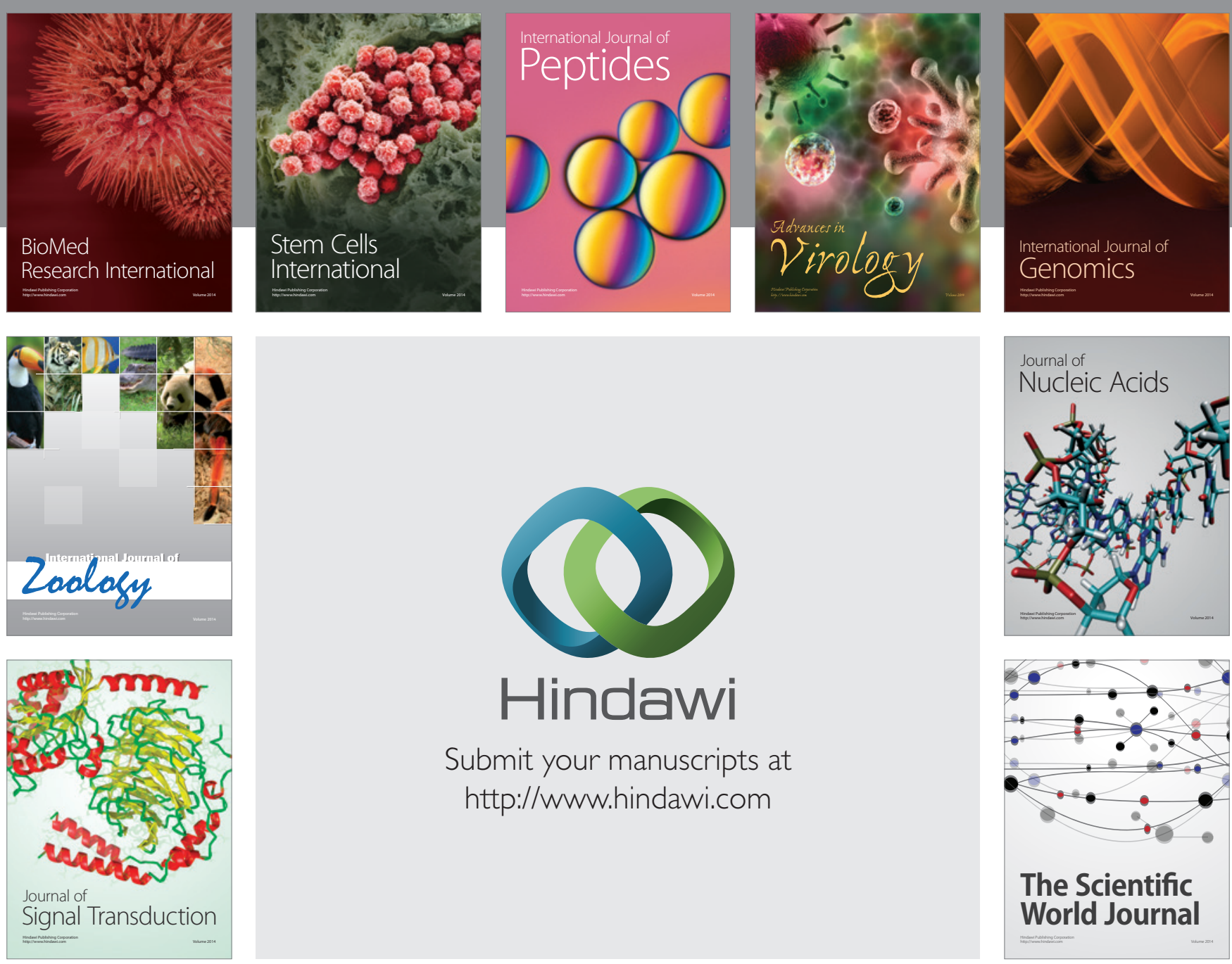

Submit your manuscripts at

http://www.hindawi.com
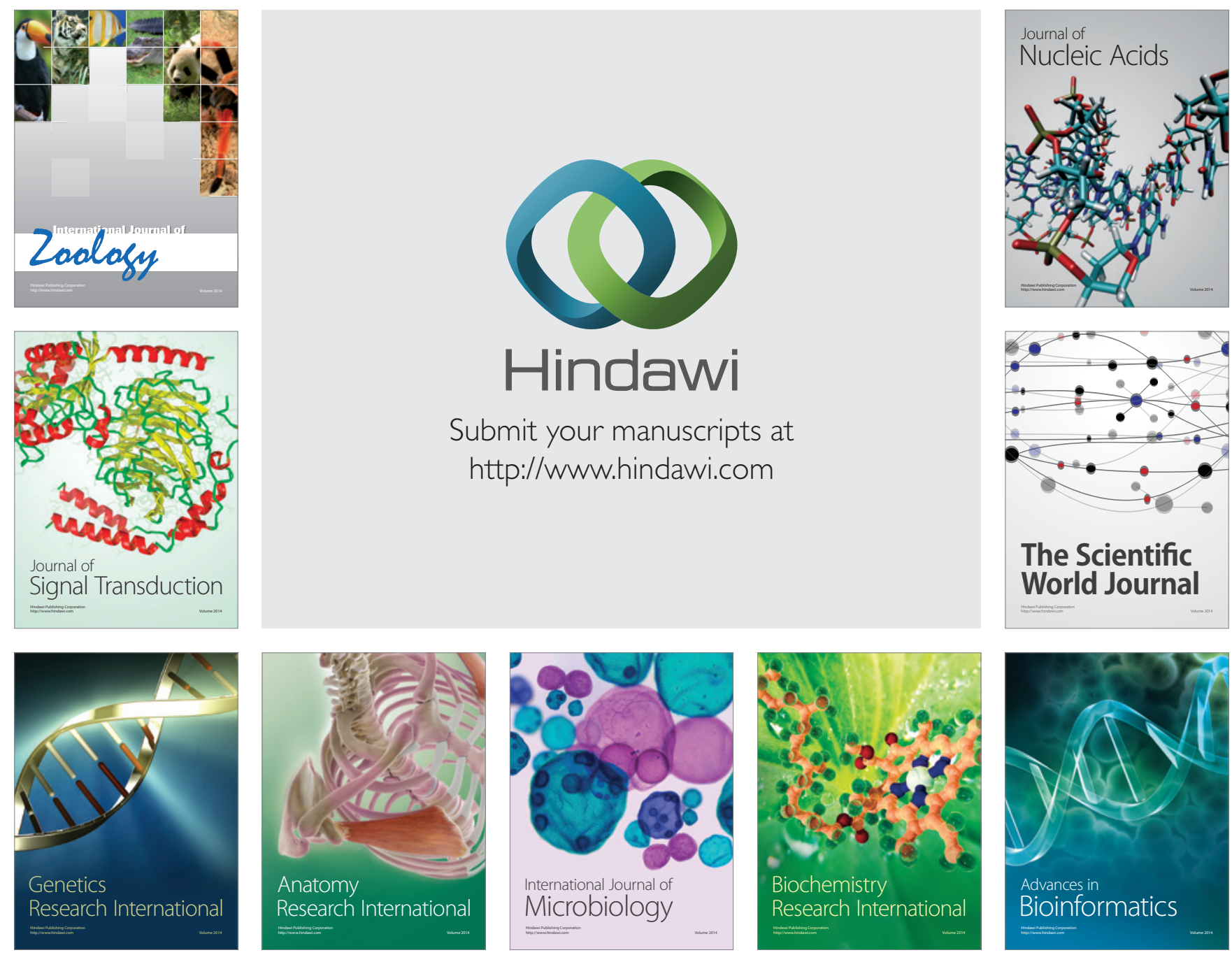

The Scientific World Journal
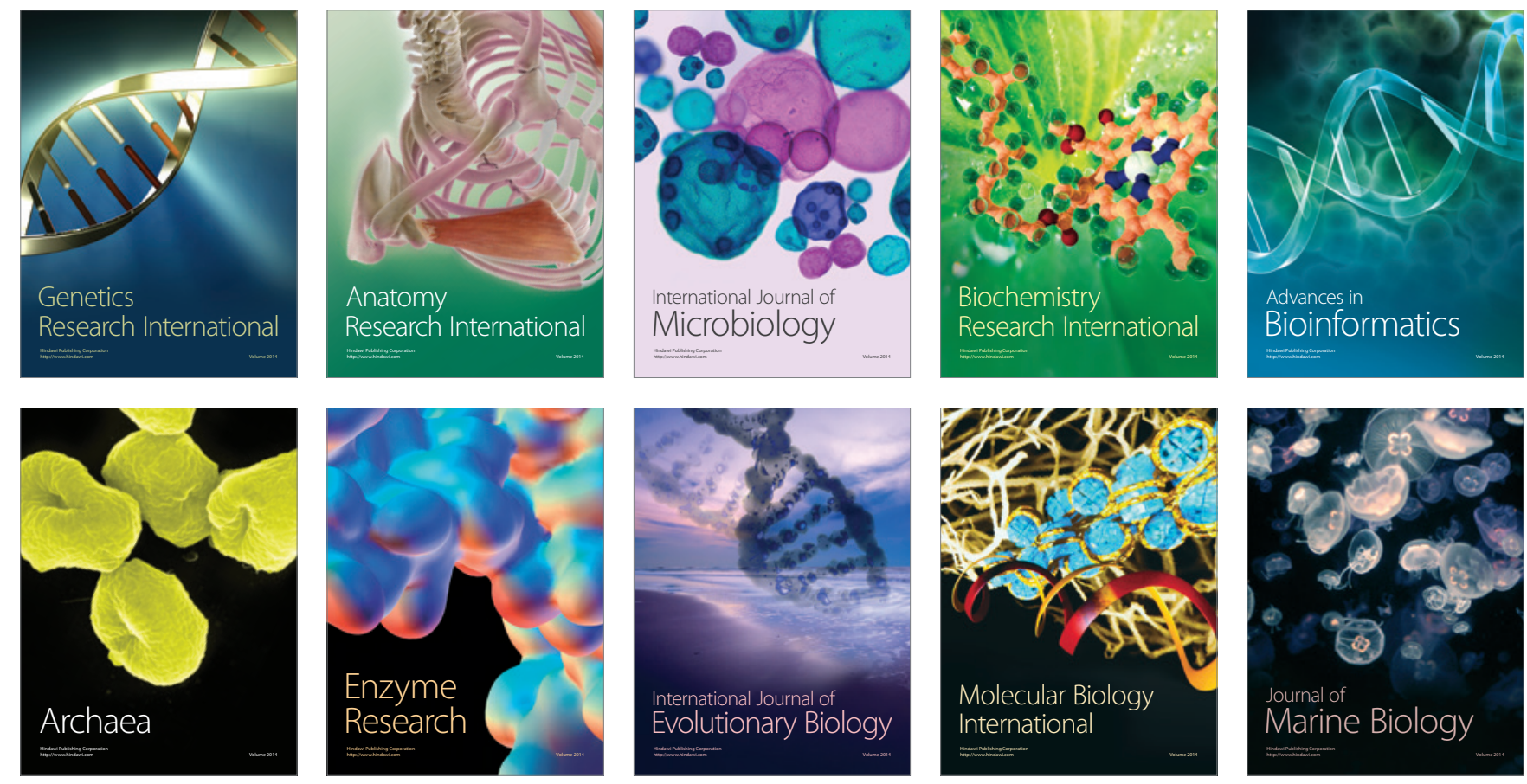